\title{
Response of Local Banana Cultivars of Manipur on Application of Organic Manures towards Uptake of Macro-Nutrients and Total Soluble Solid
}

\author{
Ngangom Monisa Devi ${ }^{1}$, Abhinash Moirangthem ${ }^{2}$, Punabati Heisnam ${ }^{3}$, Nongthombam \\ Devachandra $^{3}$, Kimneihoi Duhlian ${ }^{4}$, R.K. Dilip Singh ${ }^{4}$ and W. Ingo Meitei ${ }^{4}$ \\ ${ }^{1} \mathrm{CAU}$, Imphal, ${ }^{2}$ U.B.K.V., ${ }^{3} \mathrm{CHF}, \mathrm{CAU}$, Pasighat; ${ }^{4} \mathrm{CAU}$, Imphal \\ *Corresponding author
}

\section{A B S T R A C T}

\begin{tabular}{l} 
Ke y w o r d s \\
Banana, Nutrient, \\
Leaf, Organic, \\
Total Soluble \\
Solid, Varieties. \\
\hline Article Info \\
\hline $\begin{array}{l}\text { Accepted: } \\
17 \text { June } 2017 \\
\text { Available Online: } \\
10 \text { August } 2017\end{array}$ \\
\hline
\end{tabular}

Keywords

Banana, Nutrient,

Leaf, Organic

Total Soluble

Solid, Varieties.

An investigation was undertaken to analyze the effect of organic manure and its combinations with chemical fertilizers to the leaf nutrient content and total soluble solid (TSS) of physiologically ripen fruits using two local cultivar viz. Maring hei (AB), Meitei hei (AB) and Dwarf Cavendish (AAA) at Horticulture Research Farm, College of Agriculture, Central Agricultural University, Iroisemba, Imphal in Factorial Randomized Block Design with twenty one different treatment combinations. From the result of the present study, it may be concluded that among the cultivars, $V_{1}$ i.e. Maring Hei (AB) responded most efficiently in nutrient uptake and among the organic manures, $\mathrm{M}_{5}$ i.e. FYM@15 kg/plant was the most efficient treatment with respect to leaf nutrient content $(\mathrm{N}, \mathrm{P}$ and $\mathrm{K})$ thereby TSS per cent of fruits which may be due to the application of appropriate combination of FYM and NPK as the FYM enhanced the water holding capacity of the soil and thereby improve the soil structure.

\section{Introduction}

Banana crop requires all the three major nutrients viz., N, P and $\mathrm{K}$ for their growth and development. The requirement of these nutrients is generally supplied by inorganic fertilizers. It is the heavy feeder of nutrients and requires large quantities of nutrients for its growth, development and yield. This is due to their size, growth rate, rooting pattern and phenomenon of bud differentiation, which has relationship with the yield. The indiscriminate intensification of production technology has led to severe land degradation. The intensive banana culture has caused a gradual decrease in soil fertility to such an extent that today 100 per cent more fertilizer is required to produce the same amount of the yield per hectare that was previously obtained. The soil loses its biological dynamic owing to repeated and indiscriminate use of agro-chemicals more particularly inorganic source of fertilizer. In recent year, a new approach for utilization of available resource viz., organic source of fertilizer approach for sustainable economic yield has already been receiving wide attention. It has also been proved experimentally that fruits produced by the application of organic manure possess good firmness and longer storage life. Organic manure and bio-fertilizer along with inorganic also produce higher values in physical parameters of finger and significantly influenced biochemical constituents viz., TSS, 
reducing sugar, non-reducing sugar, ascorbic acid and moisture content (Hazarika and Ansari, 2008). The microbial biomass $\mathrm{C}$ and $\mathrm{N}$ content was higher under the integrated used of organic manure (FYM) and inorganic fertilizers (NPK). The integration effect was felt more in plots receiving organic manure and inorganic fertilizers influencing the clay content and water holding capacity of the soil rather on silt and sand (Santhy et al., 1999). Many investigators studied the combined application of organic manures and amendments can enhance the yield, quality and post-harvest attributes of fruit crops (Akash Sharma et al., 2013). In view of the above considerations, the investigation was undertaken to analyze the effect of organic manure and its combinations with chemical fertilizers to the leaf nutrient content and total soluble solid (TSS).

\section{Materials and Methods}

The experiment was conducted at the Horticulture Research Farm Andro, College of Agriculture, Central Agricultural University, Iroisemba, Imphal during the year 2010-12. The healthy sword suckers of three varieties of banana i.e., Maringhei (AB), Meitei hei (AB) and dwarf Cavendish (AAA) were selected for the experiment. Farm yard manure (FYM), Vermicompost, Inorganic fertilizers: Nitrogen, phosphorus and potassium were supplied through urea $(46 \%)$, SSP (18\%) and MOP (60\%). The experiment was laid out in Factorial Randomized Block Design with twenty one different treatment combinations denoted by $T_{n}=V_{n} M_{n}$ where, $T=$ Treatments, $\mathrm{V}=$ Varieties and $\mathrm{M}=$ Organic Manures, details of which presented below:

\begin{tabular}{|l|l|}
\hline Varieities $\left(\mathbf{V}_{\mathbf{n}}\right)$ & Organic Manures $\left(\mathbf{M}_{\mathbf{n}}\right)$ \\
\hline \multirow{2}{*}{$\mathrm{V}_{1}$ : Maring Hei $(\mathrm{AB}) ;$} & $\mathrm{M}_{1}=$ Control \\
\cline { 2 - 2 } & $\mathrm{M}_{2}=$ Paddy Husk @ 4Kg/Plant \\
\hline \multirow{3}{*}{$\mathrm{V}_{2}=$ Meitei Hei $(\mathrm{AB})$} & $\mathrm{M}_{3}=$ Paddy Husk @ $8 \mathrm{Kg} /$ Plant \\
\cline { 2 - 2 } & $\mathrm{M}_{4}=$ FYM @ 10Kg/ Plant \\
\cline { 2 - 2 } & $\mathrm{M}_{5}=$ FYM @ 15Kg/ Plant \\
\hline \multirow{2}{*}{$\mathrm{V}_{3}=$ Dwarf Cavendish (AAA). } & $\mathrm{M}_{6}=$ Vermicompost @ 2Kg/ Plant \\
\cline { 2 - 2 } & $\mathrm{M}_{7}=$ Vermicompost @ 4Kg/ Plant \\
\hline
\end{tabular}

Plant leaf analysis and total soluble solid (TSS)

The third leaf from the apex was taken for leaf sample (Murray, 1960). Samples at shooting stages of growth were taken from the middle portion of the lamina to a width of about $45 \mathrm{~cm}$ on both sides of the midrib. The samples were then sundried as well as oven dried, powdered and stored in sealed butter paper bags for estimation of total $\mathrm{N}$ as per Microkjeldhal method (Humphries, 1956), $\mathrm{P}_{2} \mathrm{O}_{5}$ as per Colorimetric method (Jackson, 1973) and $\mathrm{K}_{2} \mathrm{O}$ as per Flame photometric method (Jackson, 1973). The total soluble solid (TSS) of the physiologically ripen fruits was also estimated as per Ema Hand Refractometer and result is expressed in percentage (Tables 1 and 2). Statistical analysis was computed on analysis of variance method as suggested by Gomez and Gomez (1984) at 5\% level of probability.

\section{Results and Discussion}

In the present investigation, even though all the plants of three cultivars of banana applied with different organic sources of nutrient in the present study, registered relatively high values with respect to chemical composition of the leaves, particularly the concentration of nitrogen, phosphorus and potassium at 
shooting stage, but $\mathrm{V}_{1}=$ Maring Hei $(\mathrm{AB})$ responded most effectively with regards to uptake of these nutrients. Irrespective of varieties, the leaf nutrient concentration and TSS \% were found to maximum in the plants applied with FYM @15 kg/plant $\left(\mathrm{M}_{5}\right)$. The higher level of leaf Nitrogen (N), Phosphorus (P) and Potassium (K) concentration will accordingly result in the increase yield in terms of fruit weight. This could also be stressed to the work of Hariprakasarao et al., (1998) amply illustrates this. The highest amount of leaf nutrients viz., NPK at shooting stage was recorded in the treatment i.e. $\mathrm{M}_{5}$ FYM @ 15 kg/plant. The concentration of leaf $\mathrm{N}, \mathrm{P}$ and $\mathrm{K}$ of leaf was found considerably higher in the cultivar "Maring hei" in all the treatments of organic manure.

The maximum concentration of leaf nitrogen observed is ascribable from the growth and activity of micro-organism present in the soil by the addition of manures which usually enhanced mineralization of organic nitrogen thus making more nitrogen available to the plant. This result is in conformity with the findings of Bhattaria and Tomar (2009). It is well established that as the level of nitrogen in the leaves increased, extra proteins are produced by the conversion of synthesized carbohydrates into amino acid in leaf resulting in larger surface area for carbon assimilation (Russell, 1975) and hence the rise in uptake of nitrogen would give higher yield.

The concentration of phosphorus on the leaf was highest on the variety "Maring hei" with the application of FYM @ 15 kg/plant which might be due to the reduction of fixation of applied $\mathrm{P}_{2} \mathrm{O}_{5}$ and thereby causing an increase in the availability to crop resulting in an increase of phosphate content in leaf. The result of the present study corroborates the earlier work of Tiwary et al., (1999) in banana who noted an increase in leaf phosphorus due to application of fertilizers.

The maximum content of potassium present in the leaf was observed in the treatment $\mathrm{M}_{5}$ i.e. FYM $15 \mathrm{~kg}$ in the variety "Maring hei". The increased level of leaf potassium concentration had indirect bearing on the increased fruit yield. This might be attributed to the influence of leaf potassium on increasing rate of photosynthesis.

The essentiality of potassium as an activation for enzymes involved in protein and carbohydrates metabolism is well established (Pridham and Dey, 1974). The significance of potassium nutrition as yield determining factor was elegantly brought out by Twyford and Walmsluy (1974) in banana. The increase in the leaf potassium as observed in the present investigation due to the use of different source of organic nutrients as the organic source of nutrient themselves contributed potassium to the nutrient pool. Since banana can uptake 100 percent applied potassium (Martin-Prevel, 1962) minimized the loss due to leaching by retaining potassium ions resulting in an increased in the uptake (Santhy et al., 1999). The increase in leaf potassium under organic supplements as observed in the present study is obvious. This corroborates the earlier finding of Gubbuk et al., (1993) who reported that the organic supplement of nitrogen considerably increase leaf potassium in banana as compared to fertilizer nitrogen.

Organic source of nutrients improved the fruit qualities in terms of total soluble solid (TSS). The improvement of fruit TSS as observed in the present investigation might be due to the higher uptake of potassium. 
Table.1 Effect of organic manures and varieties on total leaf nitrogen and phosphorus nutrient at shooting stages

\begin{tabular}{|c|c|c|c|c|c|c|c|c|}
\hline \multicolumn{5}{|c|}{ Total leaf Nitrogen (\%) } & \multicolumn{4}{|c|}{ Total leaf phosphorus (\%) } \\
\hline \multicolumn{5}{|c|}{ Cultivars } & \multicolumn{4}{|c|}{ Cultivars } \\
\hline & $\mathbf{V}_{1}$ & $\mathbf{V}_{2}$ & $\mathbf{V}_{3}$ & Mean & $\mathbf{V}_{1}$ & $\mathbf{V}_{2}$ & $\mathbf{V}_{3}$ & Mean \\
\hline $\mathbf{M}_{1}$ & 3.01 & 2.32 & 2.79 & 2.70 & 0.31 & 0.20 & 0.26 & 0.25 \\
\hline $\mathbf{M}_{2}$ & 3.04 & 2.34 & 2.83 & 2.73 & 0.32 & 0.21 & 0.27 & 0.28 \\
\hline $\mathbf{M}_{3}$ & 3.05 & 2.39 & 2.84 & 2.76 & 0.33 & 0.22 & 0.28 & 0.29 \\
\hline $\mathbf{M}_{4}$ & 3.09 & 2.43 & 2.87 & 2.79 & 0.38 & 0.24 & 0.30 & 0.31 \\
\hline $\mathbf{M}_{5}$ & 3.17 & 2.47 & 2.90 & 2.83 & 0.47 & 0.28 & 0.35 & 0.37 \\
\hline$M_{6}$ & 3.07 & 2.41 & 2.86 & 2.78 & 0.37 & 0.23 & 0.29 & 0.30 \\
\hline $\mathbf{M}_{7}$ & 3.13 & 2.45 & 2.88 & 2.82 & 0.39 & 0.25 & 0.31 & 0.32 \\
\hline Mean & 3.08 & 2.41 & 2.85 & 2.78 & 0.37 & 0.23 & 0.30 & 0.29 \\
\hline & \multicolumn{4}{|c|}{ 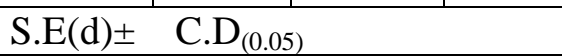 } & \multicolumn{4}{|c|}{ S.E(d) $\pm \quad$ C.D $D_{(0.05)}$} \\
\hline $\mathrm{V}$ & 0.005 & \multicolumn{3}{|c|}{0.010} & 0.001 & \multicolumn{3}{|c|}{0.003} \\
\hline M & 0.008 & \multicolumn{3}{|c|}{0.016} & 0.002 & \multicolumn{3}{|c|}{0.005} \\
\hline $\mathrm{V} \times \mathrm{M}$ & 0.013 & \multicolumn{3}{|c|}{0.029} & 0.004 & \multicolumn{3}{|c|}{0.009} \\
\hline
\end{tabular}

Table.2 Effect of organic manures and varieties on total leaf potassium at shooting stages and TSS (\%) of fruits

\begin{tabular}{|c|c|c|c|c|c|c|c|c|}
\hline \multicolumn{5}{|c|}{ Total leaf potassium (\%) } & \multicolumn{4}{|c|}{ TSS content $(\%)$} \\
\hline \multicolumn{5}{|c|}{ Cultivars } & \multicolumn{4}{|c|}{ Cultivars } \\
\hline & $\mathbf{V}_{1}$ & $\mathbf{V}_{2}$ & $\mathbf{V}_{3}$ & Mean & $\mathbf{V}_{1}$ & $\mathbf{V}_{2}$ & $\mathbf{V}_{3}$ & Mean \\
\hline $\mathbf{M}_{1}$ & 3.23 & 2.80 & 3.04 & 3.02 & 24.66 & 20.99 & 22.56 & 22.73 \\
\hline $\mathbf{M}_{2}$ & 3.24 & 2.82 & 3.05 & 3.03 & 24.99 & 21.21 & 22.77 & 22.99 \\
\hline $\mathbf{M}_{3}$ & 3.25 & 2.83 & 3.06 & 3.04 & 25.66 & 21.77 & 23.21 & 23.55 \\
\hline $\mathbf{M}_{4}$ & 3.29 & 2.86 & 3.08 & 3.08 & 26.77 & 22.32 & 24.32 & 24.47 \\
\hline $\mathbf{M}_{5}$ & 3.43 & 2.97 & 3.17 & 3.19 & 27.77 & 23.89 & 25.21 & 25.63 \\
\hline$M_{6}$ & 3.26 & 2.85 & 3.08 & 3.07 & 25.99 & 22.56 & 23.89 & 24.15 \\
\hline $\mathbf{M}_{7}$ & 3.37 & 2.88 & 3.09 & 3.10 & 27.21 & 23.21 & 24.77 & 25.06 \\
\hline \multirow[t]{2}{*}{ Mean } & 3.29 & 2.86 & 3.08 & 3.07 & 26.16 & 22.29 & 23.81 & 24.08 \\
\hline & \multicolumn{4}{|c|}{$\mathrm{S} . \mathrm{E}(\mathrm{d}) \pm \quad$ C. $\mathrm{D}_{(0.05)}$} & \multicolumn{4}{|c|}{$\mathrm{S} . \mathrm{E}(\mathrm{d}) \pm \quad$ C.D $\mathrm{D}_{(0.05)}$} \\
\hline $\mathrm{V}$ & \multicolumn{4}{|c|}{$\begin{array}{ll}0.004 & 0.009 \\
\end{array}$} & 0.170 & \multicolumn{3}{|c|}{0.344} \\
\hline $\mathrm{M}$ & \multicolumn{4}{|c|}{0.006} & 0.260 & \multicolumn{3}{|l|}{0.525} \\
\hline $\mathrm{V} \times \mathrm{M}$ & \multicolumn{4}{|c|}{0.011} & 0.450 & \multicolumn{3}{|c|}{0.923} \\
\hline
\end{tabular}

It is well established that increase in potassium concentration in plant tissue improve the sugar contents of the fruits because potassium plays an important role in the translocation of sugar. With the increase of potassium levels more starch was converted to sugar. The present investigation gets ample support from the works of Hazarika and Mohan (1990) who reported similar findings in banana. The increase in TSS (\%) content under treatment having FYM @ 15 $\mathrm{kg} /$ plant may be due to accumulation of sugars and other soluble components from hydrolysis of protein and oxidation of ascorbic acid. This corroborates with the findings of Suresh and Hasan (2001) in banana.

In conclusion, from the result of the present study, it may be concluded that among the cultivars, $V_{1}$ i.e. Maring Hei (AB) responded most efficiently in nutrient uptake and among the organic manures, $M_{5}$ i.e. FYM@ 15 kg/plant was the most efficient treatment with respect to 
leaf nutrient content ( $\mathrm{N}, \mathrm{P}$ and $\mathrm{K}$ ) thereby TSS per cent of fruits. Dwarf Cavendish (AAA), a popular banana cultivar in the country responded better than Meitei Hei (AB) but lesser than Maring Hei $(\mathrm{AB})$ under the conditions of Manipur.

\section{References}

Akash Sharma, V.K., Wali, P. and Bakshi, A. 2013. Effect of organic and inorganic fertilizers on quality and shelf life of guava (Psidium guajava). The Bioscan, 8: 1247-1250.

Bhattaria, B.P. and Tomar, C.S. 2009. Effect of Integrated Nutrient Management on leaf nutrient status of Walnut (Juglans regia L). Nepal J. Sci. Tech., 10: 63-67.

Gomez, K.K. and Gomez, A.A. 1984. Statistical Procedure for Agriculture Research. John Wiley and Sons, new York, 20-28.

Gubbuk, H., Paydas, S., and Kaska, N. 1993. Effects of different nitrogen and farmyard manure levels on the stem and finger growth and the durations of the fruit development of Cavendish and Basrai banana clones. Doga, Turk ve Ormanclk Dergisi, 17(1): 239-253.

Hariprakasarao, M., Subramanian, T.R., Ravishanker, H. And Srinivasan, V.R. 1998. Effects of different levels of nitrogen, phosphorus and potassium on leaf nutrient status and its relationship to fruit yield in passion fruit variety purple (Passiflora edulis Sims). Indian J. Hort., 45(3-4): 263-267.

Hazarika, D.N. and Mohan, N.K. 1990. Effect of levels of nitrogen and time of application on fruit quality of Jahaji banana. Banana News, 13: 26-27.

Hazarika, B.N. and Ansari, S. 2008. Effect of integrated nutrient management on quality of banana cv. Jahaji (AAA. Agri.
Society of India, 52(3/4): 175-178.

Humphries, E.C. 1956. In: Modern method of plant analysis, Pp. 468-502.

Jackson, M.L. 1973. Soil Chemical Analysis. Prentice hall of India Pvt. Ltd., New Delhi

Martin-Prevel, P. 1962. Mineral elements in banana plants and fruit bunches. Fruits, 24: 193-261.

Murray, D.B. 1960. The effect of deficiencies of the major nutrients on growth and leaf analysis of banana. Trop Agric. Trin., 30: 100-108.

Pridham, J.B. and Dey, P.M. 1974. The nature and function of higher plant galactoridases. In plant carbohydrate biochemistry (ed. J.B. Pridham. Academic Press. London.

Russell, E.W. 1975. Soil condition and plant growth ELBS and Longman. Tenth Edn.

Santhy, P., Velusamy, M.S., Murugappam, V. and Selvi, D. 1999. Effect of inorganic fertilizers and fertilizer manure combination on soil physio-chemical properties and dynamics of microbial biomass in an inceptisol. J. Indian Soc. Soil Sci., 47: 479-482.

Suresh, C.P. and Hasan, M.A. 2001. Studies on response of dwarf Cavendish banana to biofertilizer inoculation. Hort. J., 14(1): $35-41$.

Tiwary, D.K., Hasan, M.A. and Chottopadhyay, P.K. 1999. Effect of biofertilizers on soil nutrient status and microbial population in banana (Musa AAA sub- group Cavendish cv. Gaint Governor) plantation. Environ. Ecol. 17(2): 338-341.

Twyford, I.T. and Walmsluy, D. 1974. The mineral composition of the 'Robusta' banana plant, III. Uptake and distribution of mineral, constituents. Pl. Soil, 41: 471491.

\section{How to cite this article:}

Ngangom Monisa Devi, Abhinash Moirangthem, Punabati Heisnam, Nongthombam Devachandra, Kimneihoi Duhlian, R.K. Dilip Singh and Ingo Meitei, W. 2017. Response of Local Banana Cultivars of Manipur on Application of Organic Manures towards Uptake of Macro-Nutrients and Total Soluble Solid. Int.J.Curr.Microbiol.App.Sci. 6(8): 1356-1360. doi: https://doi.org/10.20546/ijcmas.2017.608.165 